\section{Dinucleotide repeat polymorphism within ERCC5 gene}

S.Samec, S.G.Clarkson*, J.Blaschak', A.Chakravarti', M.A.Morris, D.Scherly and S.E.Antonarakis Department of Genetics and Microbiology, Centre Médical Universitaire (C.M.U.). 9 avenue de Champel, 1211 Geneva 4, Switzerland and 'Department of Human Genetics, University of Pittsburgh, Pittsburgh, PA 15261, USA

Source/Description: A human genomic DNA library in EMBL3 was screened with a cDNA probe encoding the conserved I-region of ERCC5 (1), corrects the DNA repair defects in both xeroderma pigmentosum complementation group $\mathbf{G}$ and rodent ERCC group 5 (1-3). A $2.6 \mathrm{~kb}$ EcoRI fragment of one positive phage, phage $\# 10$, was found to contain a (CA 19 repeat. The repeat and surrounding sequences (EMBL accession no. X75341) lie within an intron that disrupts the codon for Gly652.

\section{PCR Primers:}

CA strand: 5'-GCAATGACTCGGTATTGG-3'

GT strand: 5'-TGGATGCTAACAAGTGGG-3'

\section{Polymorphism:}

$\begin{array}{llllll}\text { Allele } & \text { bp } & \text { Frequency } & \text { Allele } & \text { bp } & \text { Frequency } \\ \text { A1 } & 277 & .01 & \text { A7 } & 265 & .06 \\ \text { A2 } & 275 & .05 & \text { A8 } & 263 & .14 \\ \text { A3 } & 273 & .13 & \text { A9 } & 261 & .34 \\ \text { A4 } & 271 & .04 & \text { A10 } & 257 & .04 \\ \text { A5 } & 269 & .03 & \text { A11 } & 245 & .01 \\ \text { A6 } & 267 & .15 & & & \end{array}$

Heterozygosity $=0.84$ observed in 121 unrelated individuals in the CEPH reference pedigrees.

Allele Identification in Selected CEPH Individuals:

$\begin{array}{llllll}\text { 13291-01: } & \text { A3/A9 } & 1333-01: & \text { A9/A11 } & 1331-02: & \text { A7/A8 } \\ \text { 1333-01: } & \text { A9/A11 } & 13291-02: & \text { A4/A10 } & 1333-02: & \text { A2/A7 }\end{array}$

Mendelian Inheritance: Observed in all $40 \mathrm{CEPH}$ pedigrees.

Chromosomal Localization: 13q33 by FISH.

Mapping by Linkage Analyses: Two-point linkage analysis in CEPH families showed no recombination with D13S158 $(\theta=$ 0.00 ; lod $=25.59$ ). Multipoint analysis placed XPG between D13S122 and COLAA1 with odds > 1000:1.

$P C R$ Conditions: The $22 \mu \mathrm{l}$ reactions contained $10 \mathrm{mM}$ Tris- $\mathrm{HCl}$ (pH 8.3), $50 \mathrm{mM} \mathrm{KCl}, 1.5 \mathrm{mM} \mathrm{MgCl} 2,50 \mu \mathrm{M}$ of each dNTP, $400 \mathrm{ng}$ of genomic DNA, 0.75 pmoles of CA strand primer 5 '-end labelled with [ $\gamma^{-32}$ P]ATP by T4 polynucleotide kinase, 10 pmoles of CA strand primer, 20 pmoles of GT strand primer, and 1 unit of Taq polymerase (Perkin-Elmer/Cetus). Samples were heated for $7 \mathrm{~min}$ at $94^{\circ} \mathrm{C}$ then subjected to 35 cycles of $30 \mathrm{sec}$ at $94^{\circ} \mathrm{C}, 30 \mathrm{sec}$ at $51^{\circ} \mathrm{C}$, and $45 \mathrm{sec}$ at $72^{\circ} \mathrm{C}$. Amplified products were electrophoresed through $6 \%$ denaturing polyacrylamide gels.

Acknowledgements: Supported by Swiss National Science Foundation grants 31-36481.92 to S.G.C. and 31-33965.92 to S.E.A., and NIH grant HG00344 to A.C.

References: 1) Scherly,D. et al. (1993) Nature 363, 182-185.

2) O'Donovan,A. and Wood,R.D. (1993) Nature 363, 185-188.

3) MacInnes,M.A. et al. (1993) Mol. Cell. Biol. 13, 6393-6402.

\section{Tetranucleotide repeat polymorphism at the D8S346 locus}

Robyn Riley', Lesa Nelson', Jun Lu', Margaret Robertson² and Kenneth Ward 1,3.*

'Department of Obstetrics and Gynecology, ${ }^{2}$ Howard Hughes Medical Institute and ${ }^{3}$ Department of Human Genetics, University of Utah School of Medicine, 50 North Medical Drive, Room 28200, Salt Lake City, UT 84132, USA

Source/Description: The polymorphic $\left(\mathrm{A}_{3} \mathrm{~T}\right)$ repeat $\mathrm{KW} 400$ was isolated from a Sau 3A subclone of a flow-sorted chromosome 8 specific cosmid library (LA08NCO1) (1) by hybridization to an $\left(A_{3} T\right)_{20}$ oligomer. The predicted length of the amplified sequence is approximately $240 \mathrm{bp}$ (GenBank accession number L12264).

\section{PCR Primers:}

KW400A 5'-TGC ATG ACA GCC TGG GTG ACA GAA KW400B 5'-CCA CAG GTG CCC ACG CTA AGA CA

Frequency: Estimated from 200 chromosomes of unrelated Caucasian individuals.

Observed Heterozygosity Index $=63 \%$.

\begin{tabular}{|c|c|c|c|c|c|}
\hline $\begin{array}{l}\text { Allele } \\
\text { A1 } \\
\text { A2 } \\
\text { A3 }\end{array}$ & $\begin{array}{l}\text { bp } \\
252 \\
248 \\
244\end{array}$ & $\begin{array}{l}\text { Frequency } \\
0.005 \\
0.025 \\
0.065\end{array}$ & $\begin{array}{l}\text { Allele } \\
\text { A4 } \\
\text { A5 } \\
\text { A6 }\end{array}$ & $\begin{array}{l}\text { bp } \\
240 \\
236 \\
232\end{array}$ & $\begin{array}{l}\text { Frequency } \\
0.515 \\
0.380 \\
0.010\end{array}$ \\
\hline
\end{tabular}

Mendelian Inheritance: Co-dominant segregation was observed in 5 informative Caucasian familes.

Chromosomal Localization: KW400 has been assigned to chromosome 8q (Region I) by PCR of a somatic cell hybrid mapping panel (2).

PCR Conditions: PCR is performed in $25 \mu l$ containing $200 \mathrm{ng}$ DNA, $0.5 \mu \mathrm{M}$ of each primer, $1.5 \mathrm{mM} \mathrm{MgCl}, 10 \mathrm{mM}$ Tris$\mathrm{HCl}$ (pH 8.4), $40 \mathrm{mM} \mathrm{NaCl}, 200 \mu \mathrm{M}$ of each dNTP, $0.25 \mathrm{mM}$ spermidine $\mathrm{HCl}, 0.625$ units of Taq polymerase (Ampli-Taq, Perkin-Elmer/Cetus), and $0.01 \mu \mathrm{M}$ of radiolabelled KW400B (5' end-labelled with $\gamma^{32}$ P ATP $(3,000 \mathrm{Ci} / \mathrm{mmol})$ using $30 \mu \mathrm{Ci} / 10$ pmol primer). Initial denaturation was for 5 minutes at $94^{\circ} \mathrm{C}$. Amplification was for 30 cycles with denaturation at $94^{\circ} \mathrm{C}$ for 30 seconds, annealing at $60^{\circ} \mathrm{C}$ for 30 seconds, and extension at $72^{\circ} \mathrm{C}$ for 60 seconds. The products were separated by electrophoresis on a 32\% formamide, $5.7 \mathrm{M}$ urea, $7 \%$ polyacrylamide denaturing gel and analysed by autoradiography.

Acknowledgements: This work was supported in part by a grant from the Shriner's Research Foundation (\#15962).

References: 1) Evans,G.A., Lewis,K. and Rothenberg,B.E. (1989) Gene 79, 9-20. 2) Wagner,M.J., Ge,Y., Siciliano,M. and Wells,D.E. (1991) Genomics 10, 114-125.

\footnotetext{
* To whom correspondence should be addressed
} 